\title{
Cadmium Accumulation and Pathological Alterations in the Midgut Gland of Terrestrial Snail Helix pomatia $L$. from a Zinc Smelter Area: Role of Soil pH
}

\author{
Tadeusz Włostowski ${ }^{1}$ Paweł Kozłowski ${ }^{1}$ - Barbara Łaszkiewicz-Tiszczenko ${ }^{1}$. \\ Ewa Oleńska ${ }^{1}$
}

Received: 1 September 2015/Accepted: 1 February 2016/Published online: 11 February 2016

(C) The Author(s) 2016. This article is published with open access at Springerlink.com

\begin{abstract}
The purpose of this study was to determine whether cadmium $(\mathrm{Cd})$ accumulation and toxicity in the midgut gland of Helix pomatia snails living in a Cd-contaminated area were related to soil $\mathrm{pH}$. Toxic responses in the midgut gland (i.e., increased vacuolization and lipid peroxidation) occurred in $H$. pomatia snails exhibiting the highest Cd levels in the gland (265-274 $\mu \mathrm{g} / \mathrm{g}$ dry wt) and living on acidic soil ( $\mathrm{pH} 5.3-5.5)$, while no toxicity was observed in snails accumulating less $\mathrm{Cd}(90 \mu \mathrm{g} / \mathrm{g})$ and ranging on neutral soil ( $\mathrm{pH} 7.0)$, despite the fact that total soil Cd was similar in the two cases. The accumulation of $\mathrm{Cd}$ in the gland was directly related to the water extractable $\mathrm{Cd}$ in soil, which in turn correlated inversely with soil $\mathrm{pH}$, indicating that this factor had a significant effect on tissue $\mathrm{Cd}$. It appeared further that the occurrence of Cd toxicity was associated with low levels of metallothionein in the gland of snails ranging on acidic soil.
\end{abstract}

Keywords Cadmium - Snails · Midgut gland ·

Metallothionein $\cdot$ Lipid peroxidation $\cdot$ Lipofuscin

Cadmium (Cd) is an important toxic metal occurring in the environment naturally and as a pollutant emanating mainly from industrial sources such as smelting and refining of zinc and lead ores (Pan et al. 2010). Environmental Cd has been proven to induce damage primarily to the kidneys of humans (Järup and Akesson 2009), and wildlife such as ptarmigan Lagopus leucurus (Larison et al. 2000), roe deer Capreolus capreolus (Beiglböck et al. 2002), and magpies Pica pica

Tadeusz Włostowski

twlostow@uwb.edu.pl

1 Institute of Biology, University of Białystok, Ciołkowskiego 1J, 15-245 Białystok, Poland
(Włostowski et al. 2010). Under laboratory conditions, Cd has also been shown to produce toxicity in various tissues of molluscs, including Helix pomatia snails (Chabicovsky et al. 2004; Hödl et al. 2010; Amachree et al. 2013; Sheir et al. 2013). The studies demonstrated that pathological changes typical for Cd toxicity, specifically in the midgut gland, include an increased number of excretory cells with residual bodies (lipofuscin granules), programmed cell death, the disruption of mitochondrial membranes, and inflammation (Chabicovsky et al. 2004; Hödl et al. 2010; Amachree et al. 2013; Sheir et al. 2013). These alterations are thought to occur at $\mathrm{Cd}$ concentrations exceeding the capacity of metallothionein (MT), a low-molecular weight Cd-binding protein which is responsible for detoxification of the metal in the midgut gland of $\mathrm{H}$. pomatia and other species (Dallinger et al. 1997; Chabicovsky et al. 2004; Hödl et al. 2010; Baurand et al. 2015). The non-MT-bound $\mathrm{Cd}$ ions are believed to generate reactive oxygen species and peroxidation of membrane lipids, thereby producing toxicity (Roesijadi et al. 1997; Liu et al. 2009; Amachree et al. 2013).

It is known that elevated levels of $\mathrm{Cd}$ in the midgut gland of $H$. pomatia can cause toxicity (Chabicovsky et al. 2004; Hödl et al. 2010), and the level of Cd accumulation in the midgut gland of terrestrial snails has been shown to be related mainly to its total concentration in the food (plant and soil), and exposure time (Laskowski and Hopkin 1996; Dallinger et al. 2004; Hödl et al. 2010). The laboratory and field studies also revealed that soil $\mathrm{pH}$ is a very important factor influencing $\mathrm{Cd}$ bioavailability to various soil invertebrates, such as earthworms (Ma et al. 1983), snails (Pauget et al. 2012), and collembolans (Ardestani and van Gestel 2013). So far, however, little is known about the role of soil $\mathrm{pH}$ in the accumulation and toxicity of $\mathrm{Cd}$ in terrestrial snails, such as $\mathrm{H}$. pomatia ranging freely in a Cd-contaminated area. 
Therefore, the present work was designed to determine whether $\mathrm{Cd}$ accumulation and toxicity (if any) in the midgut gland of Helix pomatia snails, free living in residential areas located around a zinc smelter, were related to soil $\mathrm{pH}$. The toxicity was evaluated by assessing in the gland a number of excretory cells with lipofuscin granules (Hödl et al. 2010), and lipid peroxidation (Amachree et al. 2013). The concentration of MT that is linked to a protective effect against $\mathrm{Cd}$ toxicity was also examined.

\section{Materials and Methods}

Ten individuals of Helix pomatia snails of similar body weight (16.5-18.5 g) were collected in the first week of July 2012 from each of three residential areas situated around former zinc smelters in Katowice (southern part of Poland here referred to as Cd-contaminated sites) and from a residential area of Białystok (one of the least contaminated cities in Poland (Włostowski et al. 2014) - here referred to as a reference site) (Fig. 1). Sampling locations were prescreened for soil $\mathrm{Cd}$, as well as soil $\mathrm{pH}$ and organic matter which are known to affect $\mathrm{Cd}$ bioavailability (Pauget et al. 2012). For this purpose, three composite samples of topsoil $(0-5 \mathrm{~cm})$ were taken from each site. As can be seen in Table 1, the total content of $\mathrm{Cd}$ and organic matter in the topsoil was similar in the three $\mathrm{Cd}$-contaminated sites, but soil $\mathrm{pH}$ was significantly lower at sites $\mathrm{B}$ and $\mathrm{C}$ than at site $\mathrm{A}$.

In the laboratory, all the snails were anesthetized (5\% ethanol), decapitated and the midgut gland was removed and divided into three portions. One portion (about $200 \mathrm{mg}$ wet weight) was dried at $60^{\circ} \mathrm{C}$ for $48 \mathrm{~h}$ and used for determination of $\mathrm{Cd}$ and water (to calculate a dry weight conversion factor). Another one was fixed in $4 \%$ formaldehyde for histological examination. The third portion was frozen and kept at $-80^{\circ} \mathrm{C}$ until analysis of MT and lipid peroxidation. After thawing, a portion (about $250 \mathrm{mg}$ ) of this organ was transferred to $1.0 \mathrm{~mL}$ chilled $0.25 \mathrm{M}$ sucrose and homogenized with a Teflon pestle in a glass homogenizer. An aliquot $(0.2 \mathrm{~mL})$ was taken for determination of lipid peroxidation. The remaining homogenate was centrifuged at $20,000 \times g$ for $20 \mathrm{~min}$ at $4^{\circ} \mathrm{C}$, and the resulting supernatant was removed for MT assay. The data were expressed on a dry weight basis, using dry weight conversion factors.

$\mathrm{Cd}$ content in the midgut gland of all H. pomatia snails was determined as follows: a portion of the organ $(60-70 \mathrm{mg}$ dry weight) was digested at $200^{\circ} \mathrm{C}$ for $40 \mathrm{~min}$ in a mixture of redistilled nitric acid (70 \%) (Sigma-Aldrich) $(2.5 \mathrm{~mL}$ ), $30 \% \mathrm{H}_{2} \mathrm{O}_{2}$ (Sigma-Aldrich) $(0.25 \mathrm{~mL})$ and deionized water $(2.25 \mathrm{~mL}$ ), using a Mars 6 microwave oven (CEM Corporation, Matthews, NC, USA); Cd as well as zinc (Zn), copper $(\mathrm{Cu})$ and lead $(\mathrm{Pb})$ analyses of these solutions were carried out by electrothermal atomic absorption spectrometry (AAS), using a Thermo iCE 3400 instrument with Zeeman correction (Thermo Electron Manufacturing Ltd, Cambridge, UK). Quality assurance procedures included the analysis of reagent blanks and standard reference material (Bovine liver 1577 c - National Institute of Standards and Technology, Gaithersburg, MD). The precision expressed as relative standard deviation (RSD) of 10 measurements of the same sample was $5 \%-8 \%$, and the recoveries of $\mathrm{Cd}, \mathrm{Zn}, \mathrm{Cu}$ and $\mathrm{Pb}$ were $88 \%-98 \%$.

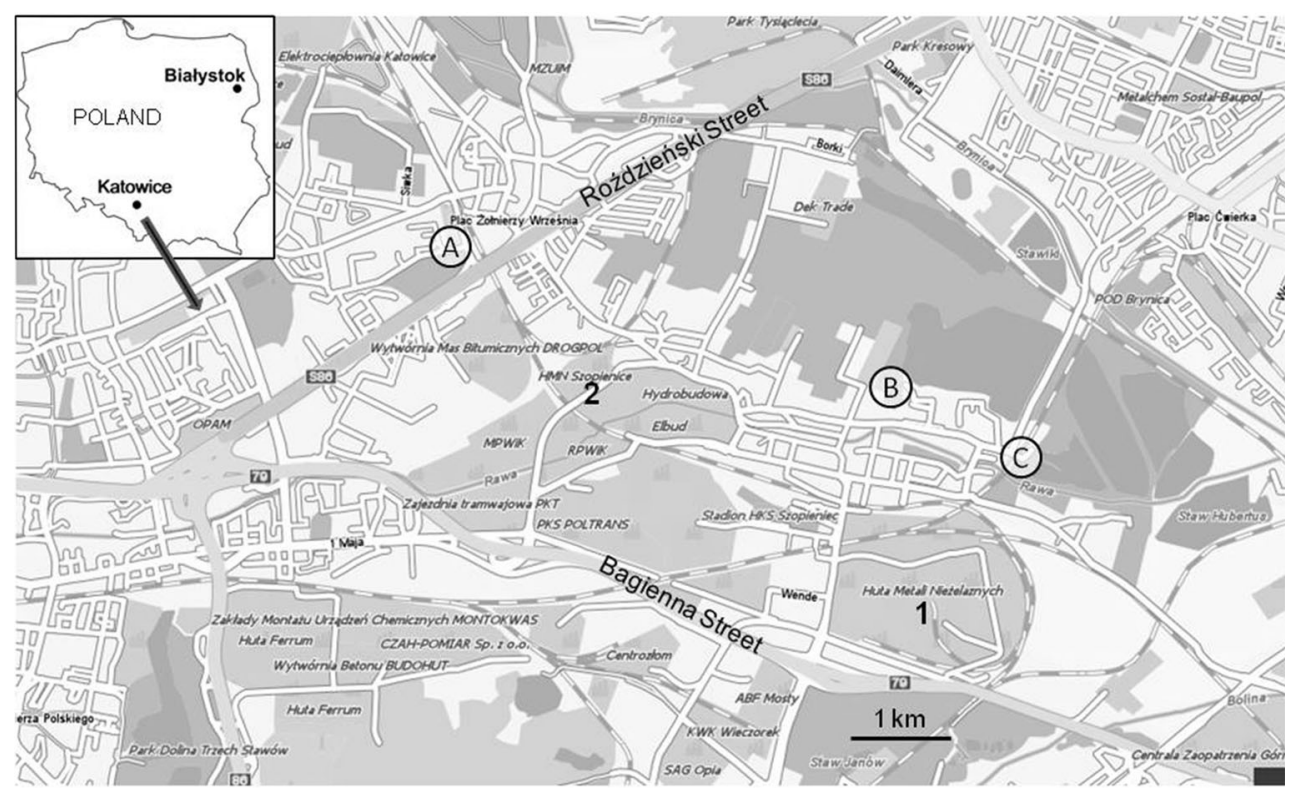

Fig. 1 Map showing location of a reference (Białystok) and zinc smelter area (Katowice). $A, B$ and $C$ indicate sampling sites in Katowice. 1 and 2 indicate locations of former zinc smelters 
Table 1 Concentrations of total $\mathrm{Cd}$, water extractable $\mathrm{Cd}, \mathrm{pH}$ and organic matter content of soil from a reference and zinc smelter area (Katowice)

\begin{tabular}{|c|c|c|c|c|}
\hline & Białystok (reference site) & Katowice A & Katowice B & Katowice $\mathrm{C}$ \\
\hline Total soil $\mathrm{Cd}(\mu \mathrm{g} / \mathrm{kg})$ & $100 \pm 30^{\mathrm{a}}$ & $2100 \pm 250^{\mathrm{b}}$ & $1860 \pm 300^{\mathrm{b}}$ & $1960 \pm 350^{\mathrm{b}}$ \\
\hline Water extractable $\mathrm{Cd}(\mu \mathrm{g} / \mathrm{kg})$ & $1.0 \pm 0.20^{\mathrm{a}}$ & $10.00 \pm 2.10^{\mathrm{b}}$ & $48.0 \pm 8.0^{\mathrm{c}}$ & $55.0 \pm 5.0^{\mathrm{c}}$ \\
\hline Soil pH & $7.25 \pm 0.10^{\mathrm{a}}$ & $7.01 \pm 0.05^{\mathrm{a}}$ & $5.50 \pm 0.05^{\mathrm{b}}$ & $5.30 \pm 0.10^{\mathrm{b}}$ \\
\hline Organic matter $(\%)$ & $5.1 \pm 0.7^{\mathrm{a}}$ & $5.5 \pm 1.0^{\mathrm{a}}$ & $6.1 \pm 0.8^{\mathrm{a}}$ & $6.0 \pm 0.9^{\mathrm{a}}$ \\
\hline
\end{tabular}

Data are presented as mean \pm SD for $\mathrm{n}=3$. Means in the same row marked with a different superscript letter are significantly different $(p<0.05)$ (ANOVA and Duncan's multiple range test)

In the case of soil Cd two different extractions were performed. To measure total $\mathrm{Cd}$ concentration, $0.2 \mathrm{~g}$ of soil (passed through a $1 \mathrm{~mm}$ sieve) was extracted at $180^{\circ} \mathrm{C}$ for $15 \mathrm{~min}$ with concentrated nitric acid $(4.5 \mathrm{~mL})$ and $\mathrm{HF}$ $(1.5 \mathrm{~mL}$ ) (Method 3052, US EPA 1996) in a Mars 6 microwave oven. Samples of Montana II soil 2711a (NIST) were also analyzed in an identical manner to check accuracy of the method. The recovery of Cd was $90 \%-95 \%$. To measure available $\mathrm{Cd}$ concentration, $0.5 \mathrm{~g}$ of the soil was extracted with $2.0 \mathrm{~mL}$ deionized water for $24 \mathrm{~h}$. The soil suspensions were centrifuged at $30,000 \times g$ for $30 \mathrm{~min}$ and the supernatants were analyzed for $\mathrm{Cd}$ by electrothermal AAS. Soil $\mathrm{pH}$ was determined in soil suspensions $(1: 2.5$ soil to water ratio) incubated for $24 \mathrm{~h}$, using a $\mathrm{pH}$ meter. Organic matter content was measured from loss-on-ignition $\left(600^{\circ} \mathrm{C}, 2 \mathrm{~h}\right)$.

Metallothionein in the midgut gland was determined by a Cd-saturation method (Włostowski et al. 2010). Briefly, a $0.1 \mathrm{~mL}$ sample was incubated for 10 min with $1.0 \mathrm{~mL}$ Tris- $\mathrm{HCl}$ buffer containing $1.0 \mu \mathrm{g} \mathrm{Cd} / \mathrm{mL}$. To remove nonMT-bound $\mathrm{Cd}$, bovine hemoglobin was added and the sample was heated at $95^{\circ} \mathrm{C}$ and centrifuged. Cd bound to MT was determined by AAS. MT was expressed in $\mu \mathrm{g} \mathrm{Cd}$ bound to the protein/g tissue.

Lipid peroxidation was assessed by measuring malondialdehyde (MDA) formation, using the thiobarbituric acid (TBA) assay (Ohkawa et al. 1979). Briefly, to $0.2 \mathrm{~mL}$ of the tissue homogenate, $0.2 \mathrm{~mL}$ of $8.1 \%$ sodium dodecyl sulfate, $1.5 \mathrm{~mL}$ of $20 \%$ acetic acid, $1.5 \mathrm{~mL}$ of $0.8 \%$ TBA and $0.6 \mathrm{~mL}$ of water were added. The reaction mixture was heated at $95^{\circ} \mathrm{C}$ for $1 \mathrm{~h}$. After cooling, $1.0 \mathrm{~mL}$ of water and $5.0 \mathrm{~mL}$ of butanol/pirydyne mixture were added. Absorbance of the organic phase was determined at $532 \mathrm{~nm}$. The results were expressed as TBARS $(\mathrm{nmol} / \mathrm{g})$.

The fixed portions of the midgut gland were dehydrated in ethanol and xylene, embedded in paraffin, cut into $5 \mu \mathrm{m}$ sections (Leica microtome), and stained with hematoxylin and eosin for microscopic examination (Zawistowski 1975). The number of excretory cells per tubule cross-section was estimated.

Data were expressed as mean $\pm \mathrm{SD}$. They were analyzed by one-way analysis of variance (ANOVA) followed by the Duncan's multiple range test (when required, the variables were normalized using $\log _{10}$ transformation). Differences at $p<0.05$ were considered statistically significant. The simple regression analysis was used to examine the relationship between $\mathrm{Cd}$ accumulation in the midgut gland and water extractable $\mathrm{Cd}$ in soil, and between the water extractable $\mathrm{Cd}$ and soil $\mathrm{pH}$. All the statistical analyses were performed using IBM SPSS Statistics 21 program (IBM Corporation, Somers, NY, USA).

\section{Results and Discussion}

All $H$. pomatia snails caught in Cd-contaminated sites (Katowice A, B and C) and in a reference site (Białystok) had normal gross morphology; for the purposes of this study only animals of similar body mass were selected, to avoid the possibility of confounding effects on $\mathrm{Cd}$ accumulation due to different body masses (Dallinger 1994). Although total $\mathrm{Cd}$ concentration in soil was similar in the three contaminated sites (Table 1), the accumulation of $\mathrm{Cd}$ in the midgut gland of $H$. pomatia snails differed significantly $(p<0.01)$ amongst the sites (Table 2$)$; the snails from sites $\mathrm{B}$ and $\mathrm{C}$ accumulated threefold higher amounts of $\mathrm{Cd}$ than those inhabiting site $\mathrm{A}$, and 50-fold higher than those living in a reference site. As can be seen in Tables 1 and 2, and Fig. 2, the accumulation of $\mathrm{Cd}$ in the gland correlated significantly with the water extractable $\mathrm{Cd}$ in soil, suggesting that the available fraction of this metal could account for the observed differences. Furthermore, the simple regression analysis revealed that in the contaminated area the water extractable $\mathrm{Cd}$ correlated inversely with soil $\mathrm{pH}$ (Fig. 3; Table 1), indicating that this factor could have a significant effect on $\mathrm{Cd}$ accumulation in H. pomatia snails.

The midgut gland was also analyzed for MT content, a well-known protective molecule (Table 2). In general, the Cd-binding capacity of MT in this organ followed a pattern similar to that of $\mathrm{Cd}$ concentration; however, the capacity of MT exceeded the total concentration of Cd only in snails from a reference site and $\mathrm{Cd}$-contaminated site $\mathrm{A}$, but $\mathrm{Cd}$ 
Table 2 Body and organ weights, cadmium and metallothionein levels, lipid peroxidation (TBARS) and number of excretory cells, and zinc, copper and lead concentrations in the midgut gland of Helix pomatia snails from a reference and zinc smelter area (Katowice)

\begin{tabular}{lcccc}
\hline & Białystok (Reference site) & Katowice A & Katowice B & Katowice C \\
\hline Body weight $(\mathrm{g})$ & $17.0 \pm 0.8^{\mathrm{a}}$ & $17.2 \pm 1.0^{\mathrm{a}}$ & $17.3 \pm 0.6^{\mathrm{a}}$ & $17.5 \pm 0.5^{\mathrm{a}}$ \\
Midgut gland weight $(\mathrm{g})$ & $1.45 \pm 0.18^{\mathrm{a}}$ & $1.52 \pm 0.15^{\mathrm{a}}$ & $1.51 \pm 0.13^{\mathrm{a}}$ & $1.56 \pm 0.14^{\mathrm{a}}$ \\
Cadmium $(\mu \mathrm{g} / \mathrm{g})$ & $6.10 \pm 2.40^{\mathrm{a}}$ & $90.3 \pm 20.4^{\mathrm{b}}$ & $265 \pm 70^{\mathrm{c}}$ & $274 \pm 90^{\mathrm{c}}$ \\
Metallothionein $(\mu \mathrm{g} \mathrm{Cd} / \mathrm{g})$ & $8.00 \pm 2.50^{\mathrm{a}}$ & $102 \pm 17.0^{\mathrm{b}}$ & $200 \pm 45^{\mathrm{c}}$ & $210 \pm 50^{\mathrm{c}}$ \\
TBARS $(\mathrm{nmol} / \mathrm{g})$ & $180 \pm 27^{\mathrm{a}}$ & $210 \pm 26^{\mathrm{a}}$ & $300 \pm 25^{\mathrm{b}}$ & $338 \pm 32^{\mathrm{b}}$ \\
Excretory cells/tubule & $3.20 \pm 0.50^{\mathrm{a}}$ & $4.05 \pm 0.55^{\mathrm{a}}$ & $6.90 \pm 0.50^{\mathrm{b}}$ & $7.30 \pm 0.45^{\mathrm{b}}$ \\
Zinc $(\mu \mathrm{g} / \mathrm{g})$ & $305 \pm 200^{\mathrm{a}}$ & $7715 \pm 1500^{\mathrm{b}}$ & $9675 \pm 2500^{\mathrm{b}}$ & $9800 \pm 1700^{\mathrm{b}}$ \\
Copper $(\mu \mathrm{g} / \mathrm{g})$ & $18.8 \pm 5.3^{\mathrm{a}}$ & $165 \pm 52^{\mathrm{b}}$ & $140 \pm 43^{\mathrm{b}}$ & $130 \pm 45^{\mathrm{b}}$ \\
Lead $(\mu \mathrm{g} / \mathrm{g})$ & $7.38 \pm 2.52^{\mathrm{a}}$ & $34.9 \pm 3.5^{\mathrm{b}}$ & $18.1 \pm 4.1^{\mathrm{c}}$ & $15.1 \pm 3.2^{\mathrm{c}}$ \\
\hline
\end{tabular}

Data are presented as mean \pm SD for $\mathrm{n}=10$. Means in the same row marked with a different superscript letter are significantly different $(p<0.05)$ (ANOVA and Duncan's multiple range test)

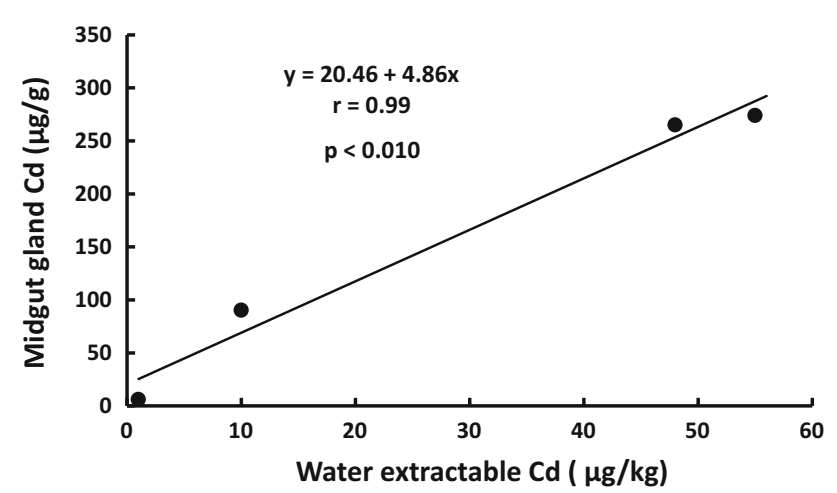

Fig. 2 The relationship of water extractable $\mathrm{Cd}$ in soil to the midgut gland $\mathrm{Cd}$ in Helix pomatia snails under study (mean values from Tables 1 and 2 were compared)

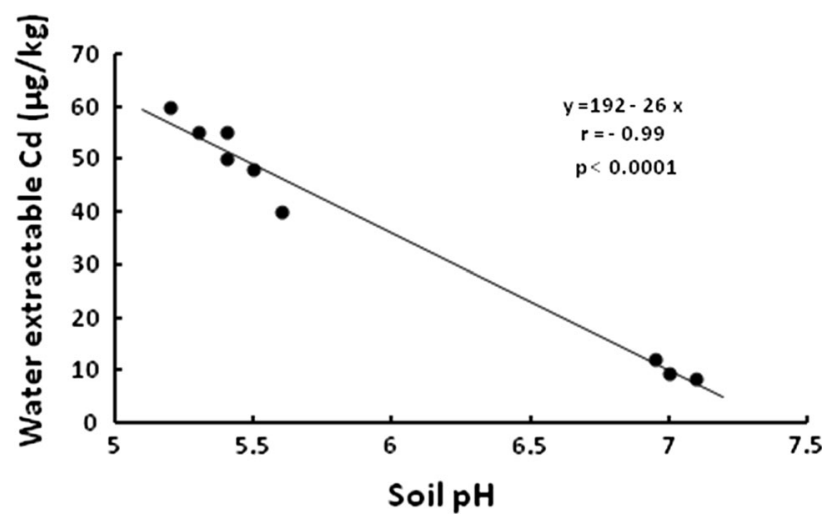

Fig. 3 The relationship of soil $\mathrm{pH}$ to the water extractable $\mathrm{Cd}$ in soil from a zinc smelter area. Soil samples $(n=3)$ from each of the three $\mathrm{Cd}$-contaminated sites were used in the analysis

level exceeded MT capacity (by $65 \mu \mathrm{g} / \mathrm{g}$ ) in animals ranging in sites $\mathrm{B}$ and $\mathrm{C}$ (Table 2).

It has previously been demonstrated in laboratory conditions that $\mathrm{Cd}$ intoxication of $H$. pomatia snails increases the formation of lipofuscin granules (residual bodies) in the excretory cells of the midgut gland epithelium (Hödl et al.
2010). In the present study, $H$. pomatia snails with the highest $\mathrm{Cd}$ concentration in the gland (sites $\mathrm{B}$ and $\mathrm{C}$ ) exhibited an increased number of excretory cells in the epithelium, but without residual bodies; in contrast, the reference animals and those living in Cd-contaminated site A had significantly fewer excretory cells, but containing lipofuscin granules (Fig. 4, Table 2). Likewise, lipid peroxidation (TBARS) in the midgut gland of snails from sites $\mathrm{B}$ and $\mathrm{C}$ was significantly higher than that in animals from the two other sites (Table 2).

The present study demonstrated that a relatively low soil $\mathrm{pH}$ substantially increases $\mathrm{Cd}$ accumulation in the midgut gland of $H$. pomatia snails free ranging in the metal contaminated area. This effect was probably indirect, through the consumption of Cd-contaminated plants. These animals feed mainly on plants (Dallinger et al. 2004; Pauget et al. 2015), and a low soil pH increases Cd solubility and availability, particularly for uptake by plants (Erikson et al. 1996). It is also possible that the ingestion of soil, and $\mathrm{Cd}$ uptake via the foot epithelium could contribute, at least to some degree, to this effect (Coeurdassier et al. 2002; Pauget et al. 2015).

The involvement of soil $\mathrm{pH}$ in the accumulation of $\mathrm{Cd}$ in tissues of other animals has also been demonstrated. For instance, Pauget et al. (2012) have found that an acid soil $\mathrm{pH}$ increases $\mathrm{Cd}$ accumulation kinetics in the snail Cantareus aspersus. Also, an inverse correlation between soil $\mathrm{pH}$ and $\mathrm{Cd}$ accumulation in the liver and kidneys of big and small mammals has been documented (Włostowski et al. 2006). Thus, a low soil $\mathrm{pH}$ appears to increase tissue $\mathrm{Cd}$ levels in various animals, thereby raising the risk of toxicity. Indeed, the toxicity in the midgut gland occurred in $H$. pomatia snails exhibiting the highest $\mathrm{Cd}$ levels (265-274 $\mu \mathrm{g} / \mathrm{g}$ ) and living on acidic soil, while no toxicity was observed in snails accumulating less $\mathrm{Cd}(90 \mu \mathrm{g} /$ $\mathrm{g}=0.8 \mu \mathrm{mol} / \mathrm{g}$ ) and ranging on neutral soil, despite the fact that total soil Cd concentration was similar in the two cases (Table 2). 


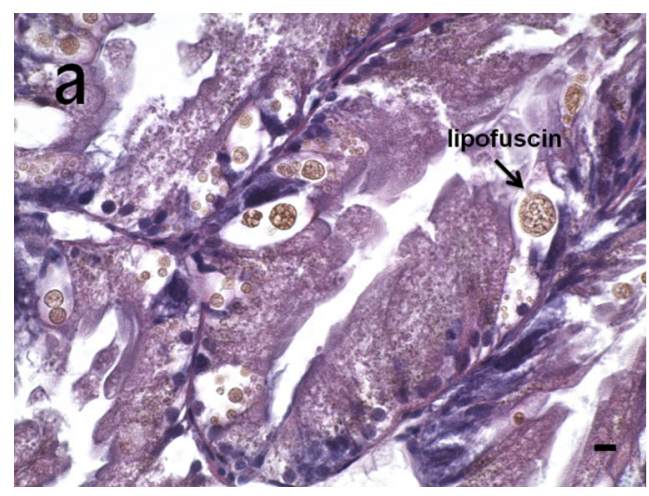

Fig. 4 Representative photomicrograph of a midgut gland section from the Helix pomatia snails (a) ranging in a reference (Białystok) and zinc smelter area - Katowice $\mathrm{A}$, and $\mathbf{b}$ living in a zinc smelter

The results of the present study are in agreement with those of Hödl et al. (2010), who demonstrated in laboratory conditions that pathological changes in the midgut gland of $H$. pomatia, such as an increased number of excretory cells with lipofuscin granules, occurred only at $\mathrm{Cd}$ levels that exceeded a threshold of $0.8 \mu \mathrm{mol} / \mathrm{g}$. These authors also revealed that MT protein became fully occupied by $\mathrm{Cd}$ ions when their concentration exceeded the threshold, and further Cd loading led to the interactions with cellular macromolecules and enzymes, thereby inducing toxicity. It is therefore likely that the non-MT-bound Cd ions were responsible for the induction of oxidative stress (TBARS) and histopathological alterations in the midgut gland of $H$. pomatia snails examined in the present study. Importantly, Cd-induced oxidative stress is thought to lead to irreversible degradation of macromolecules and the degradation products (lipofuscin) are accumulated in residual bodies (Hödl et al. 2010). Thus, the number of residual bodies in the excretory cells should increase rather than decrease, as was observed in the present work (Fig. 4).

Although the precise mechanism for the observed decline in residual bodies is unknown, this phenomenon may be explained, at least partly, by the fact that at high $\mathrm{Cd}$ tissue levels the rate of lipofuscin granule release by excretory cells into the tubule lumen may be enhanced (Hödl et al. 2010). Furthermore, H. pomatia snails from the zinc smelter areas were also chronically exposed to other metals $(\mathrm{Zn}, \mathrm{Cu}, \mathrm{Pb})$ which could contribute to these changes (Zaldibar et al. 2008). However, in contrast to $\mathrm{Cd}$, the concentrations of $\mathrm{Zn}$ and $\mathrm{Cu}$ were similar in the snails from three contaminated sites in Katowice, and the accumulation of $\mathrm{Pb}$ was significantly higher in animals from site A than sites B and C (Table 2). Thus, these metals were probably not involved solely, but could potentiate $\mathrm{Cd}$ toxicity in the midgut gland. It is also possible that the presence or absence of lipofuscin granules in excretory cells may have been influenced by the diurnal activity of

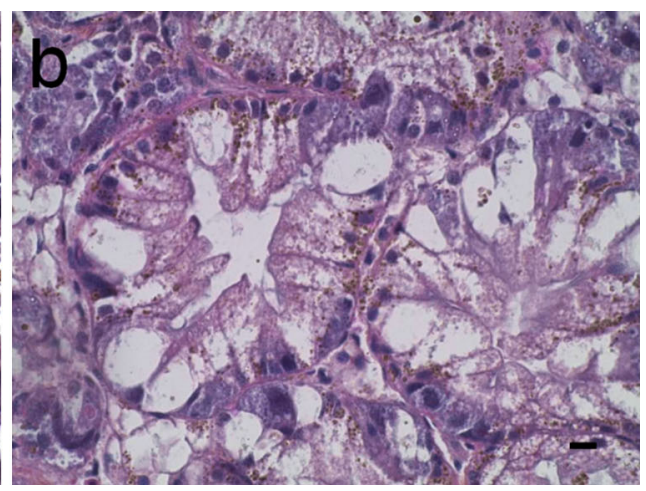

area - Katowice B und C. Note the presence (a) and absence (b) of lipofuscin granules within large vacuoles of excretory cells. Scale bar $20 \mu \mathrm{m}$

snails or preceding estivation due to dry weather conditions. Further studies are needed to determine why the histological picture of the midgut gland epithelium of freeliving $H$. pomatia snails is different from that observed in snails accumulating comparable $\mathrm{Cd}$ concentrations under laboratory conditions (Hödl et al. 2010).

In conclusion, the results of the present study showed that a relatively low soil $\mathrm{pH}$ dramatically increased the accumulation of $\mathrm{Cd}$ in the midgut gland of $\mathrm{H}$. pomatia snails free ranging in a zinc smelter area. The accumulated $\mathrm{Cd}$ appeared to induce toxicity in the gland, with $\mathrm{Cd}$ ions not bound to MT likely being responsible for these observed effects.

Acknowledgments The study was supported financially by the University of Białystok (BST-114).

Open Access This article is distributed under the terms of the Creative Commons Attribution 4.0 International License (http://creative commons.org/licenses/by/4.0/), which permits unrestricted use, distribution, and reproduction in any medium, provided you give appropriate credit to the original author(s) and the source, provide a link to the Creative Commons license, and indicate if changes were made.

\section{References}

Amachree D, Moody AJ, Handy RD (2013) Comparison of intermittent and continuous exposures to cadmium in the blue mussel Mytilus edulis: accumulation and sub-lethal physiological effects. Ecotoxicol Environ Saf 95:19-26

Ardestani MM, van Gestel CAM (2013) Using a toxicokinetics approach to explain the effect of soil $\mathrm{pH}$ on cadmium bioavailability to Folsomia candida. Environ Pollut 180:122-130

Baurand PE, Pedrini-Martha V, de Vaufleury A, Niederwanger M, Capelli N, Scheifler R, Dallinger R (2015) Differential expression of metallothionein isoforms in terrestrial snail embryos reflects early life stage adaptation to metal stress. PLoS ONE 10(2):e0116004

Beiglböck C, Steineck T, Tataruch F, Ruf T (2002) Environmental cadmium induces histopathological changes in kidneys of roe deer. Environ Toxicol Chem 21:1811-1816 
Chabicovsky M, Klepal W, Dallinger R (2004) Mechanisms of cadmium toxicity in terrestrial pulmonates: programmed cell death and metallothionein overload. Environ Toxicol Chem 23:648-655

Coeurdassier M, Gomot-de Vaufleury A, Lovy C, Badot PM (2002) Is the cadmium uptake from soil important in bioaccumulation and toxic effects for snails? Ecotoxicol Environ Saf 53:425-431

Dallinger R (1994) Invertebrate organisms as biological indicators of heavy metal pollution. Appl Biochem Biotech 48:27-31

Dallinger R, Berger B, Hunziker P, Kägi JHR (1997) Metallothionein in snail $\mathrm{Cd}$ and $\mathrm{Cu}$ metabolism. Nature 388:237-238

Dallinger R, Lagg B, Egg M, Schipflinger R, Chabikovsky M (2004) $\mathrm{Cd}$ accumulation and Cd-metallothionein as a biomarker in Cepaea hortensis (Helicidae, Pulmonata) from laboratory exposure and metal-polluted habitats. Ecotoxicology 13:757-772

Erikson J, Oborn I, Jansson G, Andersson A (1996) Factors influencing Cd content in crops. Swed J Agric Res 26:125-133

Hödl E, Felder E, Chabicovsky M, Dallinger R (2010) Cadmium stress stimulates tissue turnover in Helix pomatia: increasing cell proliferation from metal tolerance to exhaustion in molluscan midgut gland. Cell Tissue Res 341:159-171

Järup L, Akesson A (2009) Current status of cadmium as an environmental health problem. Toxicol Appl Pharmacol 238:201-208

Larison JR, Likens GE, Fitzpatrick JW, Crock JG (2000) Cadmium toxicity among wildlife in the Colorado Rocky Mountains. Nature 406:181-183

Laskowski R, Hopkin SP (1996) Accumulation of $\mathrm{Zn}, \mathrm{Cu}, \mathrm{Pb}$ and $\mathrm{Cd}$ in the garden snail (Helix aspersa): implications for predators. Environ Pollut 91:289-297

Liu J, Qu W, Kadiiska MB (2009) Role of oxidative stress in cadmium toxicity and carcinogenesis. Toxicol Appl Pharmacol 238:209-214

Ma W, Edelman T, van Beersum I, Jans T (1983) Uptake of cadmium, zinc, lead, and copper by earthworms near a zinc-smelting complex: influence of soil $\mathrm{pH}$ and organic matter. Bull Environ Contam Toxicol 30:424-427

Ohkawa H, Ohishi N, Yagi K (1979) Assay of lipid peroxides in animal tissues by thiobarbituric acid reaction. Anal Biochem 95:351-358

Pan JL, Plant JA, Voulvoulis N, Oates CJ, Ihlenfeld C (2010) Cadmium levels in Europe: implications for human health. Environ Geochem Health 32:1-12
Pauget B, Gimbert F, Scheifler R, Coeurdassier M, de Vaufleury A (2012) Soil parameters are key factors to predict metal bioavailability to snails based on chemical extractant data. Sci Total Environ 431:413-425

Pauget B, Faure O, Conord C, Crini N, de Vaufleury A (2015) In situ assessment of phyto and zooavailability of trace elements: a complementary approach to chemical extraction procedures. Sci Total Environ 521:400-410

Roesijadi G, Brubacher LI, Unger ME, Anderson RS (1997) Metallothionein mRNA induction and generation of reactive species in molluskan hemocytes exposed to cadmium in vitro. Comp Biochem Physiol C 118:171-176

Sheir SK, Handy RD, Henry TB (2013) Effect of pollution history on immunological responses and organ histology in the marine mussel Mytilus edulis exposed to cadmium. Arch Environ Contam Toxicol 64:701-716

US EPA (1996) Method 3052: microwave assisted acid digestion of siliceous and organically based matrices. http://www.epa.gov/ osw/hazard/testmethods/sw846/online/index.htm

Włostowski T, Bonda E, Krasowska A (2006) Free-ranging European bisons accumulate more cadmium in the liver and kidneys than domestic cattle in north-eastern Poland. Sci Total Environ 364:295-300

Włostowski T, Dmowski K, Bonda-Ostaszewska E (2010) Cadmium accumulaton, metallothionein and glutathione levels, and histopathological changes in the kidneys and liver of magpie (Pica pica) from a zinc smelter area. Ecotoxicology 19:1066-1073

Włostowski T, Kozłowski P, Łaszkiewicz-Tiszczenko B, Oleńska E, Aleksandrowicz O (2014) Accumulation of cadmium in and its effect on the midgut gland of terrestrial snail Helix pomatia $L$. from urban areas in Poland. Bull Environ Contam Toxicol 93:526-531

Zaldibar B, Cancio I, Soto M, Marigomez I (2008) Changes in celltype composition in digestive gland of slugs and its influence in biomarkers following transplantation between a relatively unpolluted and a chronically metal-polluted site. Environ Pollut 156:367-379

Zawistowski S (1975) Histological technique, histology and histopathology. PZWL, Warsaw 